\title{
ADAPTASI ALAT UKUR KETERLIBATAN PEMBELAJAR DARING PADA MAHASISWA DI INDONESIA
}

\author{
Sakina Rahmania*, Lucia R.M. Royanto \\ Psikologi Pendidikan, Universitas Indonesia
}

\section{Edcomtech}

\section{Jurnal Kajian Teknologi Pendidikan}

Volume 6, No 2, Oktober 2021

173-185

DOI: 10.17977/um039v6i12021p173

\section{Submitted 25-02-2021 \\ Accepted 10-05-2021}

\section{Corresponding Author*}

Sakina Rahmania

Universitas Indonesia

Jl. Margonda Raya, Pondok Cina, Kecamatan Beji, Kota Depok, Jawa Barat 16424, Indonesia

Email: sakina.rahmania@ui.ac.id

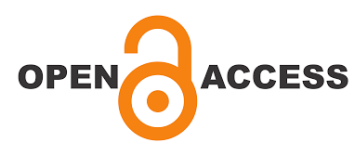

\begin{abstract}
Abstrak
Pembelajaran daring merupakan metode pembelajaran yang 'normal' sejak diberlakukannya kebijakan sekolah dari rumah oleh pemerintah. Keterlibatan pelajar dalam pembelajaran daring perlu diteliti untuk mengukur efektivitas kegiatan belajar mengajar yang telah diselenggarakan, namun sejauh ini belum ada alat ukur keterlibatan pelajar daring di Indonesia. Terdapat alat ukur bernama Online Student Engagement Scale yang telah teruji reliabilitas dan validitasnya dalam mengukur keterlibatan pelajar daring pada mahasiswa di Amerika. Oleh karenanya, untuk dapat digunakan pada konteks pembelajaran daring di Indonesia, peneliti bertujuan untuk mengadaptasi alat ukur tersebut sesuai dengan panduan dan metode adaptasi alat ukur lintas budaya yang terdiri dari beberapa tahapan, yaitu (1) penerjemahan awal, (2) sintesis hasil terjemahan, (3) penerjemahan kembali, (4) kaji komite ahli, (5) uji coba, (6) pengumpulan dokumentasi alat ukur. Berdasarkan uji coba terhadap 156 mahasiswa di berbagai universitas negeri dan swasta Indonesia, diperoleh nilai koefisien reliabilitas sebesar 0,936. Validitas konstruk dari alat ukur ini dilakukan dengan metode analisis faktor konfirmatori dengan hasil koefisien validitas berkisar 0,453-0,949. Selain itu, peneliti juga melakukan uji kesesuaian model dengan teknik structural equation modeling (SEM) dan mendapat hasil model fit yang moderat. Dengan demikian, hasil adaptasi alat ukur keterlibatan mahasiswa dalam pembelajaran daring ini valid dan reliabel untuk digunakan dalam penelitian mendatang guna mengevaluasi tingkat keterlibatan mahasiswa dalam pembelajaran daring.
\end{abstract}

Kata Kunci: keterlibatan pelajar; mahasiswa; pembelajaran daring; teknologi pembelajaran; alat ukur

\begin{abstract}
Online learning is a 'new normal' learning method since the policy of school from home has been established by the government due to Covid-19 pandemic. Student engagement in online learning environment needs to be evaluated to measure the effectiveness of teaching and learning activities. So far, there has not been any measuring tool for online student engagement in Indonesia. There is a measuring tool called 'Online Student Engagement (OSE)' that has been proved for its reliability and validity in measuring online student engagement among American Students. Hence, to be used in the context of online learning in Indonesia, this reaserch is aimed to adapt the OSE by following the guidelines and methods of crosscultural adaptation of self-report measures which include (1) translation, (2) synthesis, (3) back translation, (4) expert committee review, (5) pretesting, (6) submission and appraisal of all written reports. This instrument consists of 19 items that represent the four dimensions of student engagement. Based on pretesting on 156 college students from various university in Indonesia, the reliability coefficient of this adapted instrument is 0,936 . The
\end{abstract}


confirmatory factor analysis (CFA) of this measurement shows its validity coefficient ranging from 0,453-0,949. The structural equation modeling also shows that the adapted instrument obtained a moderate model fit. Thus, the Online Student Engagement Scale adaptation are valid and reliable for use in future research to evaluate the level of student engagement in online learning environment.

Keywords: student engagement; college student; online learning; instructional technologies; measuring instrument.

\section{LATAR BELAKANG}

Kegiatan pembelajaran jarak jauh yang disebabkan oleh pandemi coronavirus disease (covid-19) telah berjalan selama satu tahun ajaran sejak tahun 2020. Berbagai institusi pendidikan, tak terkecuali perguruan tinggi, berusaha untuk menjalankan himbauan pemerintah dalam menyelenggarakan kegiatan pembelajaran dengan mengadaptasi dan memanfaatkan berbagai sumber teknologi yang tersedia. Salah satu teknologi yang sangat bermanfaat di masa pandemi ini adalah teknologi informasi dan komunikasi dalam jaringan, yang memungkinkan para pengajar untuk dapat melaksanakan kegiatan belajar mengajar secara jarak jauh, atau dikenal dengan pembelajaran dalam jaringan atau daring (online learning). Pembelajaran daring memanfaatkan berbagai fitur dalam teknologi daring untuk memfasilitasi mahasiswa dalam mencapai tujuan pembelajaran meskipun tidak dilakukan secara konvensional dan tatap muka di dalam kelas (Dumford \& Miller, 2018). Oleh karenanya, berbagai perguruan tinggi di Indonesia, baik negeri maupun swasta, memilih pembelajaran daring sebagai metode pembelajaran jarak jauh.

Bagi sebagian besar mahasiswa di Indonesia, pembelajaran daring ini merupakan metode pembelajaran yang relatif baru (Harususilo, 2020). Pandemi Covid-19 ini memaksa perguruan tinggi dan universitas untuk memindahkan pembelajaran konvensional ke beberapa bentuk pembelajaran daring (Hodges et al., 2020). Meskipun tak dapat dipungkiri, terdapat sebagian mahasiswa yang terbiasa menggunakan fitur dalam teknologi daring sebagai sarana dan sumber belajar melalui perangkatnya, seperti komputer/laptop dan handphone (Setiyani, 2010). Namun, dengan berada di rumah masing - masing dan melakukan kegiatan pembelajaran secara jarak jauh merupakan tantangan tersendiri bagi mahasiswa untuk tetap konsisten dalam mengikuti pelajaran yang diberikan, dan bagi pengajar untuk dapat melakukan kegiatan pembelajaran secara efektif (Huang, 2020).

Meskipun pembelajaran daring merupakan solusi untuk tetap melaksanakan kegiatan belajar mengajar dalam kondisi darurat seperti saat ini, namun tidak dapat dipungkiri bahwa tingginya tingkat retensi efektivitas pembelajaran dan menurunnya minat belajar peserta didik merupakan isu utama dalam pembelajaran daring, bahkan sejak sebelum adanya pandemi covid-19 (Agarwal \& Kaushik, 2020). Hal tersebut dibuktikan dengan hasil survei yang dilakukan oleh Lembaga Komunikasi Perguruan Tinggi (LKPT) Pimpinan Pusat Ikatan Pelajar Nahdlatul Ulama (PP IPNU) terhadap 419 mahasiswa perguruan tinggi di Indonesia mengenai pembelajaran daring di tengah pandemi ini, mayoritas mahasiswa menjawab bahwa metode pembelajaran daring dirasa tidak efektif, yakni sebesar $69,45 \%$ dari total responden (Rochim, 2020). Salah satu penyebab dari rendahnya efektivitas pembelajaran daring adalah keterlibatan mahasiswa yang juga rendah (Angelino et al., 2007; Lee et al., 2015). Banna et al. (2016) menekankan bahwa keterlibatan mahasiswa merupakan solusi utama dari isu - isu seperti mahasiswa yang terisolir, penurunan minat belajar, dan tingkat kelulusan pembelajaran daring. Mahasiswa perlu dilibatkan dalam kegiatan belajar mengajar, terutama dalam pembelajaran yang dilaksanakan secara 
daring, agar mahasiswa dapat memahami suatu materi pelajaran secara mendalam.

Keterlibatan mahasiswa dalam kegiatan pembelajaran daring merupakan hal yang penting untuk mengindikasikan bahwa kegiatan pembelajaran yang disampaikan oleh pengajar berjalan secara efektif dan mahasiswa mendapatkan pengalaman belajar yang bermakna (Paulsen \& McCormick, 2020). Kahu (2013) mengatakan bahwa keterlibatan mahasiswa dalam pembelajaran mencakup kombinasi dari beberapa dimensi yang berasal dari internal mahasiswa, yaitu perilaku, kognisi, emosi dan konasi. Pendapat Kahu (2013) tersebut mengacu pada penelitian yang dilakukan oleh Handelsman et al. (2005) yang menggambarkan keterlibatan mahasiswa sebagai refleksi dari motivasi yang dilihat melalui perilaku, kognitif dan emosi mahasiswa serta tindakan yang terarah dan persistensi dalam mencapai tujuan akademik mahasiswa (Handelsman et al., 2005).

Keterlibatan belajar mahasiswa dalam pembelajaran konvensional dapat diamati secara langsung oleh pengajar karena kegiatan belajar mengajar umumnya dilakukan secara tatap muka di dalam kelas. Sementara dalam pembelajaran daring, pengajar dan mahasiswa melakukan kegiatan belajar mengajar di tempat yang terpisah dan berjauhan, sehingga kegiatan belajar lebih banyak dilakukan secara mandiri oleh mahasiswa, akibatnya pengajar hanya memiliki sedikit kesempatan untuk mengamati keterlibatan belajar mahasiswa. Selain itu menurut Dixson (2015) alat ukur yang dikembangkan secara khusus untuk mengukur keterlibatan belajar peserta didik dalam pembelajaran daring masih sangat terbatas. Oleh karenanya, la kemudian menuangkan dimensi keterlibatan belajar konvensional yang dikembangkan oleh Handelsman et al. (2005) ke dalam konteks pembelajaran daring. Dixson (2015) mendefinisikan keterlibatan mahasiswa adalah mengenai energi, waktu, pikiran, usaha dan perasaan yang dicurahkan oleh mahasiswa dalam kegiatan belajar dan hubungan yang mereka bangun dengan konten/materi, pengajar dan sesama mahasiswa yang ditunjukkan melalui kemampuan, partisipasi, kinerja dan emosi.

\section{Dimensi Keterlibatan Pembelajar:}

Dimensi Partisipasi (keterlibatan perilaku). Dimensi ini merujuk pada partisipasi dan keterlibatan langsung dalam kegiatan akademik di lingkungan pembelajaran daring, misalnya kehadiran, partisipasi pada kegiatan belajar, menaati aturan dan mengerjakan tugas (Jimerson et al., 2003). Partisipasi mahasiswa dalam lingkungan pembelajaran daring dapat berupa kontribusi mahasiswa dalam forum diskusi, kontribusi mahasiswa dalam mengerjakan tugas kelompok, dan sebagainya.

Dimensi keahlian atau kognitif (keterlibatan kognitif).

Dimensi ini mengarah pada kualitas proses kognitif dan strategi belajar mahasiswa terhadap tugas akademik (Handelsman et al., 2005). Dimensi ini disebut sebagai dimensi keahlian (skills) karena merepresentasikan keterlibatan mahasiswa dengan keahlian belajar mahasiswa (misalnya seperti membuat catatan penting dari materi yang diberikan, membaca cermat, dan sebagainya). Kahu (2013) berpendapat bahwa dimensi kognitif merujuk pada regulasi diri mahasiswa dan penggunaan strategi yang dirasa paling efektif dalam mempelajari suatu materi secara mendalam. Dimensi kognitif ini juga meliputi motivasi untuk belajar serta menggunakan strategi kognitif dan metakognitif dalam belajar (Fredricks et al., 2004).

Dimensi emosi (keterlibatan emosi).

Dimensi emosi ini menggambarkan emosi yang dirasakan mahasiswa pada proses pembelajaran maupun terhadap tugas-tugas akademik yang diberikan Handelsman et al. (2005). Kondisi perasaan seperti bersemangat untuk mengikuti 
pembelajaran selanjutnya, mengerjakan tugas yang diberikan, hingga bersemangat untuk menerapkan pengetahuan dan keterampilan baru pada kehidupan seharihari (Dixson, 2015). Dimensi ini dianggap sangat penting untuk menumbuhkan rasa keterikatan mahasiswa terhadap lingkungan belajarnya (Fredricks et al., 2004).

Dimensi performa mahasiswa
(performance). Handelsman et al. (2005) dalam penelitiannya menemukan bahwa terdapat satu dimensi lagi yang sangat mempengaruhi keterlibatan mahasiswa dalam pembelajaran, yaitu kinerja mahasiswa. Dixson (2015) menyetujui temuan tersebut dengan tetap memasukkan dimensi performa ini pada alat ukur keterlibatan pelajar yang dimodifikasinya. Menurutnya, dimensi ini menjelaskan mengenai keterlibatan mahasiswa yang dilihat dari kinerja mereka ketika mencapai tujuannya dalam pembelajaran daring. Dimensi ini menunjukkan keterlibatan melalui tingkatan kinerja mahasiswa di kelas seperti, mendapatkan nilai yang baik, mengerjakan ujian dengan baik, dan sebagainya.

Keempat dimensi tersebut merepresentasikan keterlibatan belajar mahasiswa dan menunjukkan tingkat efektivitas pembelajaran yang berlangsung. Pengajar dapat melihat efektivitas pembelajaran yang diajarnya dengan mengukur keterlibatan belajar mahasiswa melalui empat dimensi di atas. Pada pembelajaran konvensional, pengajar dapat melakukan observasi langsung pada mahasiswanya terhadap empat dimensi keterlibatan belajar di dalam kelas dan juga menggunakan kuesioner laporan diri yang diisi oleh mahasiswa untuk mengukur keterlibatan belajarnya. Sementara pada pembelajaran daring, pengukuran keterlibatan belajar mahasiswa yang paling optimal hanya melalui kuesioner laporan diri (self-report measures). Handelsman et al. (2005) mengembangkan alat ukur self-report yang bernama Student Course Engagement
Questionnaire (SCEQ) untuk mengukur tingkat keterlibatan belajar mahasiswa yang mewakili empat dimensi di atas dalam pembelajaran konvensional. Selanjutnya pada tahun 2015, Dixson memodifikasi alat ukur tersebut ke dalam konteks pembelajaran daring yang kemudian disebut dengan Online Student Engagement Scale (OSE).

Online Student Engagement Scale (OSE) telah digunakan di beberapa universitas di Amerika untuk mengukur tingkat keterlibatan mahasiswa dalam pembelajaran daring yang telah teruji reliabilitas dan validitasnya. Sementara di Indonesia sendiri, belum ada alat ukur yang secara spesifik mengukur keterlibatan mahasiswa dalam pembelajaran daring yang mewakili dimensi partisipasi, keahlian, emosi, dan kinerja, maka menggunakan alat ukur OSE untuk mengukur keterlibatan mahasiswa daring di Indonesia merupakan langkah yang dirasa lebih tepat guna dan efisien oleh peneliti dibandingkan mengkonstruksi alat ukur baru. Namun, untuk dapat menggunakan alat ukur OSE tersebut perlu dilakukan proses adaptasi alat ukur lintas budaya yang telah ditentukan prosedurnya oleh Beaton et al. (2000) terutama untuk disiplin ilmu kesehatan dan ilmu sosial.

Adaptasi alat ukur secara lintas budaya tersebut bukan hanya menerjemahkan dengan baik secara tata bahasa saja, namun juga harus memperhatikan disesuaikan dengan budaya mengadaptasi alat ukur untuk menjaga validitas konten dari alat ukur pada tingkat konseptual di berbagai negara. Beaton et al. (2000) mengembangkan panduan yang telah digunakan selama bertahun - tahun oleh berbagai peneliti dalam proses adaptasi alat ukur yang dirancang untuk memaksimalkan pencapaian kesepadanan semantik, idiomatik, eksperiensia, dan konseptual antara kuesioner asli dengan negara pengadaptasi. 
Oleh karenanya, penelitian ini bertujuan untuk mengadaptasi alat ukur keterlibatan pelajar dalam konteks pembelajaran daring pada mahasiswa yang telah dikembangkan oleh Dixson (2015). Alat ukur tersebut dinamakan dengan Online Student Engagement (OSE) dengan merujuk pada alat ukur Student Course Engagement Questionnaire (SCEQ) yang disusun oleh Handelsman et al. (2005) yang diadaptasi dan dimodifikasi agar sesuai dengan konteks pembelajaran daring. Awalnya Dixson (2010) menyusun 30 butir pernyataan untuk mengukur keterlibatan mahasiswa daring, setelah dilakukan analisis faktor menggunakan metode ekstraksi principal axis factoring dengan promax rotation, dari 30 butir hanya 19 butir pertanyaan yang memenuhi syarat. 19 butir pernyataan tersebut kemudian digunakan untuk mengukur keterlibatan mahasiswa daring di 6 Universitas di wilayah Midwestern, Amerika Serikat dan memiliki reliabilitas Cronbach's Alpha sebesar 0,91. Alat ukur ini terdiri dari 4 dimensi keterlibatan belajar yaitu Keterampilan (keterlibatan kognitif) sebanyak 6 item, Emosi (keterlibatan emosi) sebanyak 5 item, Partisipasi (keterlibatan perilaku) sebanyak 6 item, dan Performa (motivasi) sebanyak 2 item. Online Student Engagement Scale menggunakan 5 poin skala Likert, yaitu sangat sesuai (1) hingga sangat tidak sesuai (5).

\section{METODE}

Setelah menentukan alat ukur yang digunakan, peneliti melakukan perizinan penggunaan alat ukur Online Student Engagement pada pengembangan alat ukur. Metode pengadaptasian alat ukur yang digunakan dalam penelitian ini mengikuti kaidah dan tahap - tahap adaptasi alat ukur yang dikemukakan Beaton et al. (2000). Terdapat 5 tahapan dalam proses adaptasi alat ukur dimana tiap tahapnya didokumentasikan dalam satu tahap tersendiri yaitu pendokumentasian dan penilaian kelayakan alat ukur, seperti yang ditunjukkan pada Gambar 1.

Kemudian, hasil adaptasi alat ukur diujicobakan pada 156 partisipan mahasiswa program sarjana (S1) dari universitas yang berada di berbagai wilayah Indonesia (DKI Jakarta, Jawa Barat, Jawa Tengah, Jawa Timur, Sumatera Utara, Sumatera Tengah, Kalimantan Timur, dan Kalimantan Tengah) baik negeri maupun swasta (laki-laki=82, perempuan=74; usia=18-36; $\quad M_{\text {usia }}=21$; $\mathrm{SD}=3,037)$. Teknik pengambilan sampel yang digunakan yaitu convenience sampling, karena pengambilan data dilakukan secara daring (Etikan et al., 2016). Tautan kuesioner diambil dari Google form dan dibagikan pada partisipan melalui WhatsApp. Sebelum mulai mengisi kuesioner, partisipan mengisi pernyataan kesediaan untuk mengikuti penelitian dan data demografi.

Peneliti melakukan uji reliabilitas berupa perhitungan koefisien Cronbach Alpha dengan batas minimum 0,6 (Cohen \& Swerdik, 2010) dan analisis uji daya beda item dengan melihat nilai Correlated-item total correlation (CITC) dengan batas minimum 0,3 menggunakan perangkat lunak SPSS versi 23.0 dan analisis validitas konstruk menggunakan Confirmatory Factor Analysis (CFA) dengan batas minimum dari muatan faktor tiap item adalah 0,4 (Garson, 2010) melalui perangkat lunak RStudio.

Selain itu peneliti juga akan menguji kesesuaian model alat ukur dengan melihat kriteria dari setiap kategori yaitu, baik apabila nilai CFI \& TLI >0,95; SRMR<0,08; RMSEA $<0,06$, termasuk dalam kategori cukup baik apabila nilai $\mathrm{CFI}>0,90$ dan TLI<0,95;0,08<SRMR<0,10;0,06<RMSEA<0,1 $0)$, kategori kesesuaian model yang kurang baik apabila nilai CFI \& TLI <0,90; SRMR $>0,10$; RMSEA $>0,10$ (Hu \& Bentler, 1999; Ahn, dkk., 2018) yang juga didapatkan dengan menggunakan perangkat lunak RStudio. 


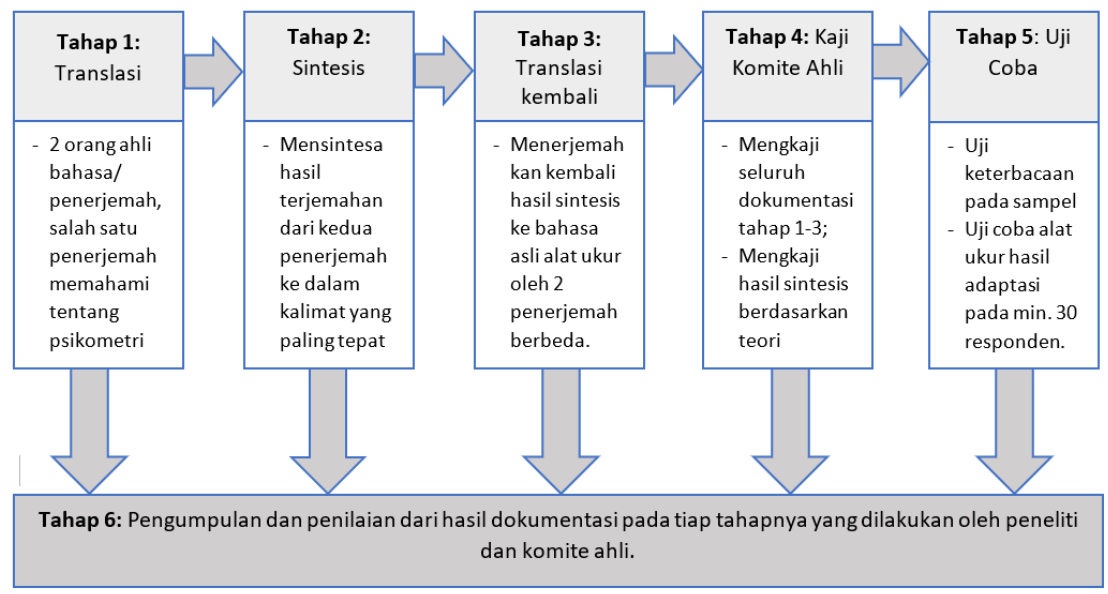

Gambar 1. Alur dari tahap dalam proses adaptasi alat ukur lintas budaya

HASIL

Proses adaptasi alat ukur telah dilakukan sesuai dengan tahapan dan kriteria dalam prosedur adaptasi alat ukur (Beaton et al., 2000).

\section{Tahap 1: Translasi ke Bahasa Indonesia}

Tahap pertama, yaitu proses translasi alat ukur Online Student Engagement ke dalam bahasa Indonesia telah dilakukan oleh dua orang translator yang memiliki keahlian dalam bahasa Inggris dengan nilai TOEFL minimal 550 atau nilai IELTS minimal 7.0), menguasai bahasa Indonesia. Selain itu, penerjemah pertama (terjemah 1) adalah orang yang awam terhadap konstruk alat ukur dengan latar belakang pendidikan sastra (non-psikologi), sementara penerjemah kedua (terjemah 2) memahami konstruk alat ukur dengan latar belakang pendidikan psikologi.

Saat melakukan proses translasi kembali ke bahasa awal, penerjemah tidak diberikan alat ukur Online Student Engagement versi asli untuk alasan objektivitas. Hasil dari translasi kembali yang dilakukan oleh kedua penerjemah menunjukkan tidak adanya perubahan makna dari terjemah sintesis dengan alat ukur versi asli.

\section{Tahap 4: Komite Ahli (Expert Review)}

Pada tahap keempat, peneliti melibatkan dua orang reviewer yang memiliki keahlian di bidang keterlibatan mahasiswa dalam pembelajaran daring. Ahli pertama adalah seorang psikolog dan bekerja sebagai konselor pendidikan di salah
Tahap 2: Sintesis Hasil Translasi

Selanjutnya di tahap kedua, yaitu sintesis hasil translasi dilakukan oleh peneliti dengan mendiskusikannya bersama dengan penerjemah-1 dan penerjemah- 2 terutama pada item yang memiliki perbedaan pendapat seperti yang tertera pada Tabel 1 . Hasil sintesis tersebut kemudian dinamakan dengan Terjemah Sintesis.

Tahap 3: Translasi Ke Bahasa Awal Kembali

Pada tahap ketiga, terjemah sintesis tersebut diberikan ke dua orang yang memiliki keahlian bahasa Inggris dengan kriteria serupa dengan penerjemah 1 dan penerjemah 2, untuk melakukan translasi kembali terjemah sintesis ke bahasa inggris. Hal ini dilakukan untuk memastikan hasil terjemah sintesis memiliki makna yang sama dengan alat ukur Online Student Engagement yang asli.

satu universitas swasta di Indonesia, yang juga menjalani kegiatan mengajar secara daring. Sementara ahli kedua merupakan tenaga pengajar fakultas ilmu pendidikan di salah satu universitas negeri di Indonesia dengan latar belakang teknologi pendidikan, yang pernah terlibat dalam penelitian dan pengembangan media pembelajaran daring. Peneliti memberikan alat ukur asli dari Online Student Engagement dan alat ukur yang sudah disintesis untuk kemudian dikaji oleh kedua ahli tersebut. Setelah mendapatkan umpan balik dari kedua ahli, terdapat beberapa item yang dikritisi oleh komite ahli dan selanjutnya peneliti 
melakukan perbaikan serta finalisasi item dari alat ukur yang sudah diadaptasi tersebut (Tabel 2). Beberapa masukan yang diberikan oleh komite ahli misalnya seperti memperha-tikan konsistensi penggunaan kata siswa atau mahasiswa, kemudian juga dengan memberikan contoh pada kata atau kalimat yang ambigu seperti pada item SK1. Namun begitu, sebagian besar dari hasil terjemah sintesis dinyatakan sudah menggambarkan konstruk dengan cukup baik.

Tabel 1. Contoh item yang telah di sintesis dari hasil translasi

\begin{tabular}{|c|c|c|c|c|}
\hline item & Item Asli & Terjemah 1 & Terjemah 2 & Terjemah Sintesis \\
\hline SK1 & $\begin{array}{l}\text { Making sure to } \\
\text { study on a regular } \\
\text { basis }\end{array}$ & $\begin{array}{l}\text { Berusaha belajar } \\
\text { secara teratur }\end{array}$ & $\begin{array}{l}\text { Memastikan untuk } \\
\text { belajar secara } \\
\text { teratur }\end{array}$ & $\begin{array}{l}\text { Saya belajar secara } \\
\text { teratur }\end{array}$ \\
\hline SK6 & $\begin{array}{l}\text { Listening/reading } \\
\text { carefully }\end{array}$ & $\begin{array}{l}\text { Menyimak } \\
\text { dengan cermat }\end{array}$ & $\begin{array}{l}\text { Mendengarkan/ } \\
\text { membaca dengan } \\
\text { seksama }\end{array}$ & $\begin{array}{l}\text { Saya menyimak/ materi } \\
\text { pembelajaran dengan } \\
\text { cermat }\end{array}$ \\
\hline EM1 & Putting forth effort & Berusaha keras & $\begin{array}{l}\text { Mengerahkan segala } \\
\text { upaya }\end{array}$ & $\begin{array}{l}\text { Saya berusaha keras } \\
\text { dalam mengikuti } \\
\text { pembelajaran daring }\end{array}$ \\
\hline EM5 & $\begin{array}{l}\text { Really desiring to } \\
\text { learn the material }\end{array}$ & $\begin{array}{l}\text { Sangat } \\
\text { bersemangat } \\
\text { untuk } \\
\text { mempelajari } \\
\text { materi }\end{array}$ & $\begin{array}{l}\text { Bersungguh - } \\
\text { sungguh dalam } \\
\text { mempelajari materi }\end{array}$ & $\begin{array}{l}\text { Saya bersungguh - } \\
\text { sungguh dalam } \\
\text { mempelajari materi }\end{array}$ \\
\hline PAR3 & $\begin{array}{l}\text { Helping fellow } \\
\text { students }\end{array}$ & $\begin{array}{l}\text { Membantu } \\
\text { sesama siswa }\end{array}$ & $\begin{array}{l}\text { Membantu rekan } \\
\text { belajar }\end{array}$ & $\begin{array}{l}\text { Saya membantu sesama } \\
\text { siswa dalam } \\
\text { pembelajaran daring }\end{array}$ \\
\hline PER & $\begin{array}{l}\text { Getting a good } \\
\text { grade }\end{array}$ & $\begin{array}{l}\text { Mendapatkan } \\
\text { nilai yang bagus }\end{array}$ & $\begin{array}{l}\text { Memperoleh nilai } \\
\text { yang bagus }\end{array}$ & $\begin{array}{l}\text { Saya memperoleh nilai } \\
\text { yang bagus dalam } \\
\text { pembelajaran daring }\end{array}$ \\
\hline
\end{tabular}

Tabel 2. Finalisasi item dari alat ukur Online Student Engagement yang sudah diadaptasi dan dikaji oleh komite ahli.

\begin{tabular}{clll}
\hline $\begin{array}{l}\text { No. } \\
\text { item }\end{array}$ & Item Asli & Terjemah sintesis & Item final \\
\hline SK1 & $\begin{array}{l}\text { Making sure to } \\
\text { study on a } \\
\text { regular basis }\end{array}$ & Saya belajar secara teratur & $\begin{array}{l}\text { Saya belajar secara teratur, di } \\
\text { luar jam kuliah (contoh: setiap } \\
\text { hari, seminggu 3x) }\end{array}$ \\
EM1 & $\begin{array}{l}\text { Putting forth } \\
\text { effort }\end{array}$ & $\begin{array}{l}\text { Saya berusaha keras dalam } \\
\text { mengikuti pembelajaran daring }\end{array}$ & $\begin{array}{l}\text { Saya berusaha keras dalam } \\
\text { mengikuti pembelajaran daring }\end{array}$ \\
EM5 & $\begin{array}{l}\text { Really desiring } \\
\text { to learn the } \\
\text { material } \\
\text { Helping fellow } \\
\text { students }\end{array}$ & $\begin{array}{l}\text { Saya bersungguh - sungguh dalam } \\
\text { mempelajari materi }\end{array}$ & $\begin{array}{l}\text { Saya membantu sesama siswa } \\
\text { dalam pembelajaran daring } \\
\text { dalam mempelajari materi } \\
\text { pembelajaran }\end{array}$ \\
PAR3 & $\begin{array}{l}\text { Saya membantu mahasiswa lain } \\
\text { dalam pembelajaran daring }\end{array}$ \\
PER & $\begin{array}{l}\text { Getting a good } \\
\text { grade }\end{array}$ & $\begin{array}{l}\text { Saya memperoleh nilai yang bagus } \\
\text { dalam pembelajaran daring }\end{array}$ & $\begin{array}{l}\text { Saya memperoleh nilai bagus } \\
\text { dalam pembelajaran daring }\end{array}$ \\
\hline
\end{tabular}


Tabel 3. Hasil pengujian daya beda masing-masing item dan nilai Cronbach's Alpha

\begin{tabular}{|c|c|c|c|c|}
\hline Dimensi & $\alpha$ & Item & CITC & $\alpha$ if Item Deleted \\
\hline \multirow{6}{*}{ Keterlibatan Kognitif (Skill) } & \multirow{6}{*}{0,834} & SK1 & 0,566 & 0,934 \\
\hline & & SK2 & 0,624 & 0,933 \\
\hline & & SK3 & 0,626 & 0,933 \\
\hline & & SK4 & 0,537 & 0,935 \\
\hline & & SK5 & 0,761 & 0,931 \\
\hline & & SK6 & 0,723 & 0,931 \\
\hline \multirow{5}{*}{ Keterlibatan Emosi (Emotion) } & \multirow{5}{*}{0,857} & EM1 & 0,707 & 0,932 \\
\hline & & EM2 & 0,729 & 0,931 \\
\hline & & EM3 & 0,616 & 0,933 \\
\hline & & EM4 & 0,685 & 0,932 \\
\hline & & EM5 & 0,774 & 0,930 \\
\hline \multirow{6}{*}{$\begin{array}{l}\text { Keterlibatan Perilaku } \\
\text { (Participation) }\end{array}$} & \multirow{6}{*}{0,881} & PAR1 & 0,721 & 0,931 \\
\hline & & PAR2 & 0,805 & 0,930 \\
\hline & & PAR3 & 0,673 & 0,932 \\
\hline & & PAR4 & 0,771 & 0,930 \\
\hline & & PAR5 & 0,483 & 0,936 \\
\hline & & PAR6 & 0,700 & 0,932 \\
\hline \multirow{2}{*}{$\begin{array}{l}\text { Keterlibatan Performa } \\
\text { (Performance) }\end{array}$} & \multirow{2}{*}{0,802} & PER1 & 0,311 & 0,938 \\
\hline & & PER2 & 0,248 & 0,940 \\
\hline
\end{tabular}

Ket. Reliabilitas $(\alpha)=0,936$ ( $p>0,001) ; N$ partisipan $=156 ; N$ item=19; item PER2 diberi warna abu-abu karena nilai CITC $<0,3$.

Tahap 5: Uji Keterbacaan dan Uji Coba Alat Ukur

Sebelum uji coba atau pre-test, peneliti melakukan uji keterbacaan pada 5 sampel dari partisipan yang sesuai dengan kriteria yang ditentukan. Hal ini dilakukan untuk memastikan bahwa alat ukur yang telah diadaptasi tersebut dapat dipahami oleh calon partisipan. Setelah mendapat-kan konfirmasi bahwa alat ukur yang telah diadaptasi dapat diterima dan dipahami dengan baik oleh kelima partisipan uji keterbacaan, kemudian alat ukur diuji cobakan kepada 156 partisipan penelitian.

Tahap 6: Pengumpulan dan penilaian dari hasil dokumentasi

Tahap ini merekapitulasi seluruh tahapan yang dilalui dari alur adaptasi alat ukur lintas budaya. Setelah melakukan uji coba dan mengumpulkan data, kemudian peneliti melakukan pengolahan data dan penilaian kelayakan alat ukur berdasarkan hasil uji coba. Hasil pengujian reliabilitas konstruk menggunakan koefisien cronbach's alpha pada alat ukur ini adalah sebesar 0,936, sehingga dapat disimpulkan alat ukur ini tergolong reliabel $(\alpha>0,6)$. Sementara hasil uji daya beda tiap item berkisar antara $0,248-0,805(p<0,001)$. Terdapat satu item yang tidak memenuhi persyaratan kriteria uji beda dari alat ukur Online Student Engagement versi Indonesia, yaitu item nomor 19 yang mewakili dimensi performa (Tabel 3). Oleh karenanya, kemudian item tersebut (Saya dapat mengerjakan tes/kuis dengan baik) dieliminir dari alat ukur yang telah diadaptasi tersebut, dengan begitu reliabilitas alat ukur ini meningkat menjadi 0,940 . Selanjutnya peneliti melakukan CFA untuk memvalidasi konstruk dari alat ukur yang telah diadaptasi dengan menggunakan perangkat lunak RStudio. Setelah dilakukan CFA akan didapatkan muatan faktor dari setiap item yang menandakan item tersebut dinyatakan valid dalam mengukur konstruk apabila nilai muatan faktor $>0,4$ (Garson, 2010). Hasilnya dapat dilihat pada Tabel 4 dibawah bahwa seluruh item pada alat ukur ini memiliki muatan faktor $>0,4$ yang artinya seluruh item dalam alat ukur ini valid dalam mengukur konstruk dari masing - masing dimensinya-(dimensi kognitif (skill) $=0,541-$ 0,794; dimensi perilaku (participation $)=0,453-0,870$; 
Tabel 4. Muatan faktor pada item Online Student Engagement versi bahasa Indonesia

\begin{tabular}{lllll}
\hline & Muatan & Faktor & (factor \\
Butir Pernyataan & loading) & & \\
\cline { 2 - 4 } & Dimensi & & \\
& SK & EM & PAR & PER \\
\hline
\end{tabular}

1. Saya belajar secara teratur, di luar jam kuliah

0,585

(contoh: setiap hari/seminggu 3x/dll)

2. Saya tetap belajar dan/atau mengerjakan tugas sampai larut $\quad 0,657$ malam (begadang)

3. Saya memeriksa catatan saat kelas daring untuk memastikan 0,661 pemahaman terkait materi ajar

4. Saya adalah mahasiswa yang terorganisir 0,541

5. Saya memperhatikan hal-hal penting pada bahan ajar yang $\quad 0,794$ disampaikan berupa bacaan, PowerPoint, atau video

6. Saya menyimak/membaca materi pembelajaran dengan 0,766 cermat

7. Saya berusaha keras dalam mengikuti pembelajaran daring (online)

8. Saya berusaha menemukan cara untuk menjadikan materi pembelajaran relevan/berkaitan dengan kehidupan

9. Saya menerapkan/mengaplikasikan materi pembelajaran dalam kehidupan sehari-hari saya

10. Saya menemukan cara agar materi yang saya pelajari menarik bagi saya

11. Saya bersungguh-sungguh dalam mempelajari materi pembelajaran

12. Saya terlibat dalam obrolan online, diskusi atau melalui email dengan dosen atau mahasiswa lain untuk membahas materi pelajaran

13. Saya berpartisipasi aktif di forum diskusi kelompok kecil

14. Saya membantu mahasiswa lain dalam pembelajaran daring (online)

15. Saya terlibat dalam percakapan online (chat, diskusi, email) untuk membicarakan materi pelajaran

16. Saya rutin memposting (tugas/pertanyaan/jawaban/dll) di forum diskusi

17. Saya berusaha mengenal mahasiswa lain dalam pembelajaran daring

18. Saya memperoleh nilai bagus dalam pembelajaran daring (online)

19. Saya dapat mengerjakan tes/kuis dengan baik

Ket. $p>0,001 ; S K=$ dimensi keterlibatan kognitif (skill); $E M=$ dimensi keterlibatan emosi; $P A R=$ dimensi keterlibatan perilaku; $P E R=$ dimensi keterlibatan performa (performance).

dimensi emosi $=0,638-0,798$; dimensi performa=0,707 - 0,949). Menariknya, pada item nomor 19 yang sebelumnya mendapatkan nilai $r<0,3 \quad(0,248)$ pada analisis muatan faktor yang dilakukan melalui CFA ini dinilai valid dalam mengukur konstruk pada dimensi performa $(0,707>$ $0,4)$. Oleh karenanya peneliti kemudian melakukan kajian literatur terkait kriteria batas minimum nilai CITC untuk uji daya beda dan mendapatkan bahwa kriteria cutoff dari nilai CITC dapat ditolerir hingga- 


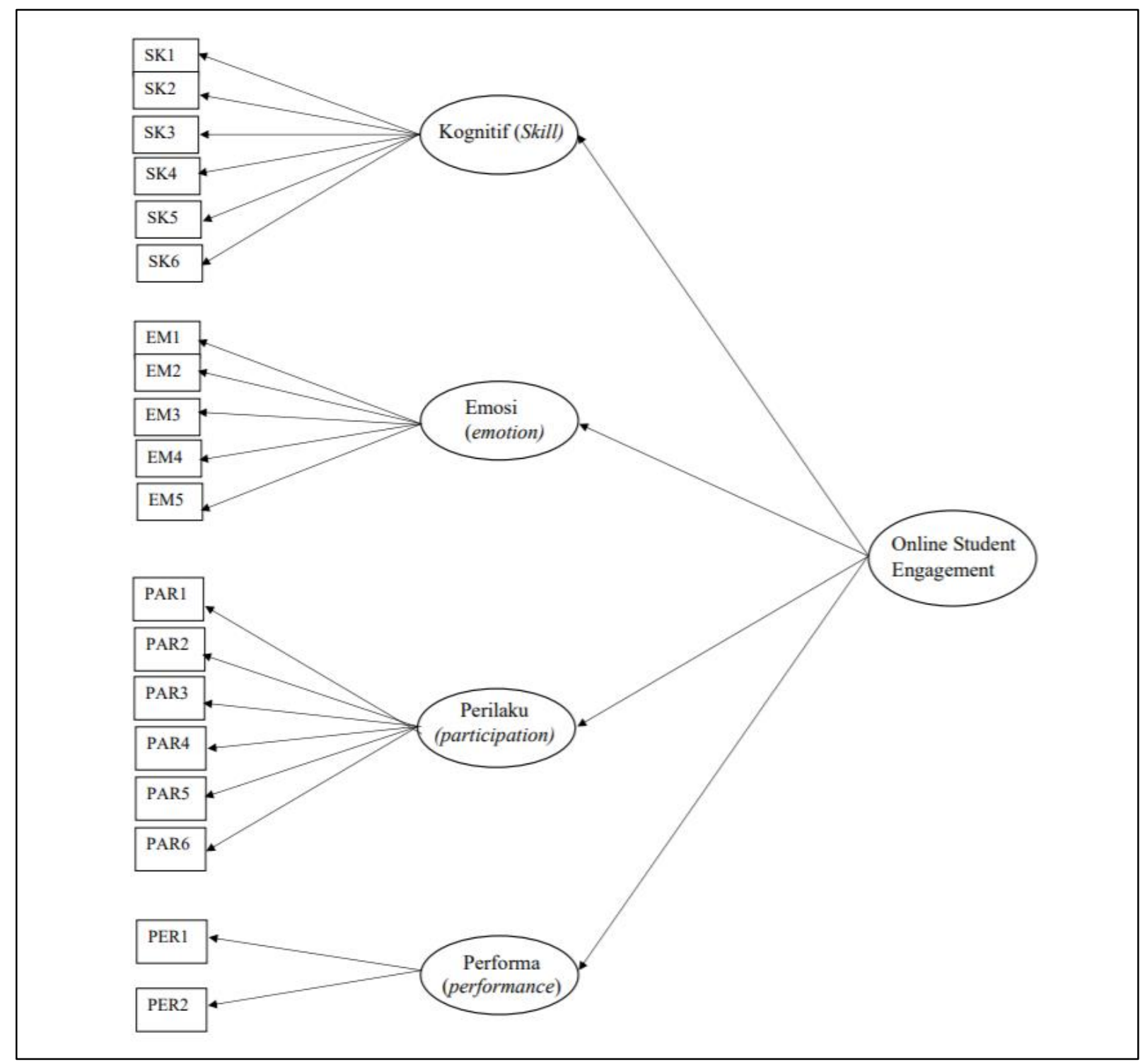

Gambar 2. Struktur model confirmatory factor analysis pada alat ukur Online Student Engagement yang di adaptasi dalam bahasa Indonesia

$r>0,2$ (Natanael, 2013) sehingga item tersebut dipertahankan oleh peneliti.

Alat ukur Online Student Engagement yang telah diadaptasi dalam bahasa Indonesia ini memiliki model sebagaimana digambarkan pada Gambar 2. Model tersebut kemudian diuji kesesuaiannya dengan melihat pada nilai comparative fit index (CFI), Tucker-Lewis index (TLI), standardized root mean square residual (SRMR) dan root mean square error approximation (RMSEA). Hasil CFI, TLI dan RMSEA menunjukkan kesesuaian model alat ukur ini tergolong moderat (cukup baik) dengan nilai $\mathrm{CFI}=0,949$ (CFI>0,90), TLI =0,940 (TLI<0,95), RMSEA = $0,061(0,06<R M S E A<0,10)$ sementara nilai SRMR menunjukkan kesesuaian model alat ukur yang tergolong baik yaitu 0,059 (SRMR< $0,08)$.

\section{PEMBAHASAN}

Semakin berkembang teknologi yang dapat digunakan dalam kegiatan pembelajaran, maka semakin meningkat kebutuhan penelitian akan keterlibatan pelajar dalam pembelajaran berbasis teknologi tersebut. Sesuai dengan 
definisinya, menurut Association for Educational Communications and Technology (AECT), teknologi dalam pendidikan dapat memfasilitasi belajar dan meningkatkan kinerja apabila pengembangan dan pemanfaatan teknologinya tepat guna (Januszewski \& Molenda, 2013). Adaptasi alat ukur keterlibatan pelajar dalam pembelajaran daring diperlukan karena adanya kesenjangan antara kebutuhan penelitian dengan ketersediaan alat ukur dalam bahasa Indonesia. Terlebih saat ini di Indonesia sudah semakin banyak institusi pendidikan terutama Perguruan Tinggi yang melaksanakan pembelajaran jarak jauh secara daring (online). Peneliti memutuskan untuk mengadaptasi alat ukur yang dikembangkan oleh Dixson (2010) setelah melakukan kajian literatur terkait pembelajaran daring dan keterlibatan mahasiswanya. Tahapan dan kriteria adaptasi mengikuti kaidah adaptasi alat ukur yang dikembangkan oleh Beaton et al. (2000).Alat ukur yang telah diadaptasi ini menunjukkan reliabilitas yang sangat baik dan juga valid untuk mengukur keterlibatan mahasiswa dalam pembelajaran daring. Selain itu juga kesesuaian dari struktur model yang disajikan oleh peneliti pun dapat diterima berdasarkan kriteria yang disampaikan oleh Hu \& Bentler (1999). Adapun keterbatasan dalam penelitian ini adalah terdapat satu item yang menunjukkan nilai uji daya beda (item discrimination) yang dapat dikatakan rendah, meskipun nilai tersebut masih berada dalam batas toleransi. Selain itu, item tersebut tetap dipertahankan mengingat hanya terdapat dua item yang mewakili konstruk dimensi performa dan item tersebut memiliki muatan faktor yang memenuhi persyaratan validitas item dari suatu alat ukur.

Umumnya pada alat ukur keterlibatan pelajar hanya mengukur tiga dimensi keterlibatan, yaitu keterlibatan kognitif, perilaku, dan emosi, namun pada alat ukur yang dikembangkan oleh Dixson (2010) ini menambahkan satu dimensi lagi yaitu performa. Hal ini disebabkan oleh adanya analisis faktor pengaruh keterlibatan pelajar yang dilakukan oleh Handelsman et al. (2005) dengan pendekatan model sosialkognitif (Dweck, 2010; Dweck \& Leggett, 1988; Molden \& Dweck, 2000) pada alat ukur Student Course Engagement Questionnaire, yang kemudian diadaptasi dan modifikasi oleh Dixson (2010) ke dalam konteks pembelajaran daring. Dalam penelitian Handelsman et al. (2005) tersebut ditemukan bahwa performa merupakan salah satu faktor yang turut membentuk keterlibatan pelajar.

\section{SIMPULAN}

Proses adaptasi alat ukur Online Student Engagement menjadi alat ukur Keterlibatan Mahasiswa dalam Pembelajaran Daring (Online) dapat dikatakan berjalan dengan baik sesuai dengan kaidah adaptasi alat ukur lintas budaya Beaton et al. (2000). Secara umum, alat ukur yang telah diadaptasi ini terbukti memiliki reliabilitas dan validitas yang baik, serta memiliki kesesuaian model yang cukup baik (moderat). Instrumen ini dapat digunakan untuk mengukur keterlibatan mahasiswa pada jenjang Pendidikan Tinggi (D3 hingga Pascasarjana) yang melaksanakan pembelajaran jarak jauh secara daring melalui berbagai platform dan manajemen sistem pembelajaran (learning management system). Adapun untuk jenjang pendidikan dasar dan menengah, peneliti menyarankan untuk melakukan adaptasi dan modifikasi lebih lanjut yang disesuaikan dengan konteks masing - masing jenjang pendidikan dalam menerapkan pembelajaran daring.

Terdapat berbagai hal yang perlu ditinjau lebih lanjut untuk mendapatkan kesesuaian model (model fit) yang lebih baik, Hal yang dapat dilakukan sebagai tindak lanjut dari keterbatasan penelitian ini adalah dengan mengevaluasi kembali penggunaan 
atau pemilihan kalimat pada alat ukur yang telah diadaptasi ini, atau dengan menganalisis hubungan antar dimensi sehingga mendapatkan nilai dengan hasil kesesuaian model yang lebih baik.

\section{REFERENSI}

Agarwal, S., \& Kaushik, J. S. (2020). Student's perception of online learning during COVID pandemic. Indian Journal of Pediatrics, 1.

Angelino, L., Keels Williams, F., \& Natvig, D. (2007). Strategies to Engage Online Students and Reduce Attrition Rates. The Journal of Educators Online, 4(2), 1-14. https://doi.org/10.9743/jeo.2007.2. 1

Banna, J., Lin, M.-F. G., Stewart, M., \& Fialkowski, M. K. (2016). Interaction matters: Strategies to promote engaged learning in an online introductory nutrition course. Physiology \& Behavior, 176(1), 100106.

Beaton, D. E., Bombardier, C., Guillemin, F., \& Ferraz, M. B. (2000). Guidelines for the Process od Cross Cultural Adaptation od Self-Report Measures. Spine, 25, 3186-3191. https://doi.org/10.1080/000163599 428823

Dixson, M. D. (2010). Creating effective student engagement in online courses: What do students find engaging? Journal of the Scholarship of Teaching \& Learning, 10(2), 1-13. https://files.eric.ed.gov/fulltext/EJ89 0707.pdf

Dixson, M. D. (2015). Measuring student engagement in the online course: the Online Student Engagement scale (OSE).(Section II: Faculty Attitudes and Student Engagement)(Report). Online Learning Journal (OLJ), 19(4), 143-157.

https://doi.org/http://dx.doi.org/10. 24059/olj.v19i4.561
Dumford, A. D., \& Miller, A. L. (2018). Online learning in higher education: exploring advantages and disadvantages for engagement. Journal of Computing in Higher Education, 30(3), 452-465. https://doi.org/10.1007/s12528-0189179-z

Dweck, C. S. (2010). Even Geniuses Work Hard. In Educational Leadership (Vol. 68, Issue 1). https://eric.ed.gov/?id=EJ896451

Dweck, C. S., \& Leggett, E. L. (1988). A SocialCognitive Approach to Motivation and Personality. Psychological Review, 95(2), 256-273.

https://doi.org/10.1037/0033295X.95.2.256

Etikan, I., Musa, S. A., \& Alkassim, R. S. (2016). Comparison of Convenience Sampling and Purposive Sampling. American Journal of Theoretical and Applied Statistics, 5(1), 1-4. https://doi.org/10.11648/j.ajtas.20160 501.11

Fredricks, J. A., Blumenfeld, P. C., \& Paris, A. H. (2004). School engagement: Potential of the concept, state of the evidence. Review of Educational Research, 74(1), 59-109.

https://doi.org/10.3102/003465430740 01059

Garson, D. (2010). Statnotes: Topics in Multivariate Analysis: Factor Analysis. https://faculty.chass.ncsu.edu/garson/ pa765/statnote.htm

Handelsman, M. M., Briggs, W. L., Sullivan, N., \& Towler, A. (2005). A Measure of College Student Course Engagement. Journal of Educational Research, 98(3), 184-192.

https://doi.org/10.3200/JOER.98.3.184192

Harususilo, Y. E. (2020). Mengembalikan "roh pendidikan" lewat pedagogi belajar daring dari rumah. Kompas.

Hodges, C., Moore, S., Lockee, B., Trust, T., \& Bond, A. (2020). The difference between emergency remote teaching and online 
learning. Educause Review, 27(1), 115.

Huang, R. (2020). The Chinese Experience in Maintaining Undisrupted Learning in COVID-19 Outbreak. In Handbook on Facilitating Flexible Learning During Educational Disruption.

Januszewski, A., \& Molenda, M. (2013). Educational technology: A definition with commentary. Routledge.

Jimerson, S. R., Campos, E., \& Greif, J. L. (2003). Toward an Understanding of Definitions and Measures of School Engagement and Related Terms. The California School Psychologist, 8(1), 7-27. https://doi.org/10.1007/bf03340893

Kahu, E. R. (2013). Framing student engagement in higher education. Studies in Higher Education, 38(5), 758-773. https://doi.org/10.1080/03075079.2 011.598505

L.-T., H., \& M., B. P. (1999). Cutoff criteria for fit indexes in covariance structure analysis: conventional criteria versus new alternatives. Structural Equation
Modeling, 6(1), 1-55. https://doi.org/https://doi.org/10.1080 /10705519909540118

Lee, E., Pate, J. A., \& Cozart, D. (2015). Autonomy Support for Online Students. TechTrends, 59, 54-61. https://doi.org/https://doi.org/10.1007 /s11528-015-0871-9

Molden, D. C., \& Dweck, C. S. (2000). Meaning and motivation. Intrinsic and Extrinsic Motivation, 131-159. https://doi.org/10.1016/b978012619070-0/50028-3

Paulsen, J., \& McCormick, A. C. (2020). Reassessing Disparities in Online Learner Student Engagement in Higher Education. Educational Researcher, 49(1), 20-29. https://doi.org/10.3102/0013189X1989 8690

Rochim. (2020). Survei IPNU: 80,67\% Mahasiswa Tak Dapat Pembelajaran Daring dari Kampus. Sindonews.

Setiyani, R. (2010). Pemanfaatan Internet Sebagai Sumber Belajar. Dinamika Pendidikan Unnes, 5(2), 117-133. https://doi.org/10.15294/dp.v5i2.4921 